\title{
Nitrogen and sulphur fertilizers effects on yield, nitrogen uptake and nitrogen use efficiency of upland rice variety on irrigated Fulvisols of the Afar region, Ethiopia
}

\author{
Kiros Habtegebrial $^{1 \star}$, Sintayehu Mersha ${ }^{2}$ and Solomon Habtu ${ }^{1}$ \\ ${ }^{1}$ Department of Land Resource Management and Environmental Protection, Mekrlle University, P. O. Box 231, \\ Mekelle Ethiopia. \\ ${ }^{2}$ Gewane College of Agriculture, P. O. Box 114, Gewane, Ethiopia.
}

Accepted 5 June, 2013

\begin{abstract}
The present study was conducted in $2009 / 10$ to investigate the effect of $\mathbf{N}$ and $\mathbf{S}$ fertilization on yield, $\mathbf{N}$ uptake, $\mathrm{N}$ use efficiency, and grain protein content of the upland NERICA-4 rice variety. The layout of the experiments was randomized complete block designs with three replications, where in 2009 crop season, the effect of five $\mathrm{N}$ rates $\left(\mathrm{N} 0=0, \mathrm{~N} 1=36, \mathrm{~N} 2=59, \mathrm{~N} 3=82\right.$ and $\mathrm{N} 4=105 \mathrm{~kg} \mathrm{~N}^{-1}$ ) without $\mathrm{S}$ and in 2010 crop season, a factorial combination of the same $N$ rates with three $S$ rates $(S 0=0, S 1=20$ and $\mathrm{S} 2=40 \mathrm{~kg} \mathrm{~S} \mathrm{ha}^{-1}$ ) were used in $2.1 \times 3 \mathrm{~m}^{2}$ plots to determine the response of the crop to $\mathrm{N}$ and $\mathrm{S}$ on irrigated Fluvisols. The application of $\mathrm{N}$ alone and in combination with $\mathrm{S}$ significantly affected $(P<0.05)$ the yield, yield components, $\mathrm{N}$ uptake, nitrogen use efficiency, and grain protein content of the rice crop. Nitrogen application alone increased the grain and total dry matter yield, average for both years by 0.7 and $2.5 \mathrm{Mg} \mathrm{ha}^{-1}$, compared to the controls (NO). The application of the same $\mathrm{N}$ rates, combined with $S$ further improved the grain and total DM yield on average by 0.5 and $1.3 \mathrm{Mg} \mathrm{ha}^{-1}$, compared to those $\mathrm{N}$ rates without $\mathrm{S}$. The leaf and grain $\mathrm{N}$ concentration, total $\mathrm{DM}$ and grain $\mathrm{N}$-yield, and the grain protein content increased with $\mathrm{N}$ applications, but they were significantly enhanced when $\mathrm{N}$ was fertilized with $\mathbf{S}$. Only the apparent $\mathbf{N}$ recovery was significant to $\mathbf{N}$ applications, but all the $\mathbf{N}$ use efficiency components were significantly affected when $\mathbf{N}$ was applied with $\mathbf{S}$. Thus, this work showed the yield response of the crop could be improved with $\mathbf{N}$ and $\mathbf{S}$ fertilization with rice producing farmers benefiting from the application of S-containing $\mathbf{N}$ fertilizers to soils deficient in these nutrients.
\end{abstract}

Key words: Alluvial soils, semiarid, upland rice, $\mathrm{N}$ and $\mathrm{S}$ interactions, Nitrogen use efficiency.

INTRODUCTION

Rice (Oryza sativa L.) is an ancient grain. More than half of the world population depends on rice for its major daily sources of food energy and protein. The importance of rice in relation to food security and socio-economic is thus self-evident (FAO, 2003). Since the past three decades, the demand for rice has grown in Africa and is considered as one of the strategic commodity crop for poverty reduction and food security assurance in the continent (FARA, 2009). Rice is believed to be introduced to Ethiopia in the early 1970 s, and today the country is 
emerging as important rice growing in Eastern Africa (Gebrekidane and Seyoum, 2006). The area under rice production in Ethiopia is estimated to have increased from 19,000 ha in 2007 to about 136,000 ha in 2009 (MoARD, 2010). Owing to its recent introduction to the country, the research and development effort so far undertaken on rice in Ethiopia is at its infancy. However, taking into consideration its productivity, varied uses, existence of vast suitable conditions (swampy, waterlogged, rainfed and irrigable lands) and possibilities of growing it where other food crops do not perform well could make rice among the promising alternative crops available for cultivation in Ethiopia, and contributing greatly towards ensuring household as well as national food security of the country.

Nearly all the rice varieties grown until recently in Ethiopia were the Asian types that have poor adaptation to upland conditions (MoARD, 2010). However, to meet the vast potential of the upland environment to grow rice, the upland rice variety "New Rice for Africa" (NERICA) has been recently introduced and grown in the different parts of the country (Zenna et al., 2008). NERICA is derived from the crossing of the African rice (Oryza. glaberrima Steud) and the Asian rice (O. sativa L.), and posses high yielding potential, early vigor, nonshattering grains, good response to fertilizer applications, short growth cycle, tolerant to drought, and resistant to pests and disease (WARDA, 2001) and most suitable in altitude below 1500 m.a.s.l (Mulugeta et al., 2011).

The Afar region is found in the rift valley of northeast Ethiopia. The land under the river basin covers a vast area of alluvial plains, estimated about 360,000 ha, in which half of it is found in the Afar region. The basin is formed from frequent flooding and sedimentation of the Awash River that flows from central highlands. The livelihood of the local population is based on agropastoral farming system. The region has recently begun introducing high yielding upland rice varieties under irrigated conditions in these alluvial plains, but the yield of the crop is low averaging about $1.5 \mathrm{Mg} \mathrm{ha}^{-1}$, limited mainly by nutrient availability (NAIA, 2003), such as nitrogen, sulphur and other nutrients.

Nitrogen is considered as the most yield-limiting nutrient in irrigated rice production around the world (Samonte et al., 2006). Sulphur is also an important nutrient for plant growth and its uptake by plants accounts 9 to $15 \%$ of $\mathrm{N}$ uptake (Inal et al., 2003). Deficiency of $S$ has long been recognized as limiting nutrient for crop production, and rice crops in particular are reported throughout the world to be affected increasingly by S-deficiency, as the use of S-free fertilizers increases (Yasmin et al., 2007). Nitrogen and S are both involved in plant protein synthesis, a process that may determines yield of crops. As a result, the requirement of $\mathrm{N}$ by plants increases when $\mathrm{N}$ is fertilized with $\mathrm{S}$, as their metabolism is coupled in the synthesis of S-containing amino acids, membrane lipids, enzymes and coenzymes (Anderson, 1990). Consequently, poor use efficiency of $\mathrm{N}$ by the plant is caused by insufficient $S$ availability to convert $\mathrm{N}$ into biomass production, which in turn may increase $\mathrm{N}$ losses from cultivated soils (Ceccotti, 1996).

Most of the soils of the study area are low in water holding capacity, soil organic matter (SOM) and sulphur contents (Yirgalem, 2001; Itanna, 2005). The deficiency of $S$ in the soils is partly exacerbated by the fact that the Ethiopian agriculture mainly emphasizes on the use of high analysis NP fertilizers that contain little $S$, continuous monocropping, seldom application of organic wastes, and the complete removal of crop residues (Habtegebrial and Singh, 2006). Many reports are present on the effect of $\mathrm{N}$ fertilization to the yield of upland rice (Oikeh et al., 2008; Shiferaw et al., 2012), but reports on the effect of $S$ on yield of the same crop and nitrogen use efficiency (NUE) when applied with $\mathrm{N}$ are seldom available. However, the appropriate rates of these nutrients required to maximize the yield, quality and NUE of rice should be known, especially for irrigated upland conditions. Therefore, this study was conducted to evaluate the effect of different $\mathrm{N}$ and $\mathrm{S}$ rates and their interactions on the yield, yield components, protein quality and NUE of NERICA-4 rice, when $\mathrm{N}$ is added alone and in combination with $S$ on Fluvisols of the Afar alluvial plains under irrigated conditions.

\section{MATERIALS AND METHODS}

\section{Study area description}

The experiment was conducted in 2009 and 2010 crop seasons (February-May) at the Gewane College of Agriculture of the Afar Region, Ethiopia $\left(10^{\circ} 01^{\prime} \mathrm{N}\right.$ and $40^{\circ} 33^{\prime} \mathrm{E}, 626 \mathrm{~m}$ a.s.I). The site is located in the semi-arid climatic zone with annual maximum and minimum temperature of 44 and $17^{\circ} \mathrm{C}$, respectively. The mean daily sunshine of the area during the crop season was $10.6 \mathrm{~h}$. The annual average rainfall of the area is lower than $400 \mathrm{~mm}$ and occurs mainly between mid-July to mid-September. The rain season is very windy (aver. $51 \mathrm{~km}^{\mathrm{day}}{ }^{-1}$ ), and rains are unreliable, highly erratic and occur with heavy downpour, making rainfed agriculture nearly impossible

The main geo-morphological unit of the experimental area is recognized as a recent alluvial plain, resulting from the flooddeposits of the Awash River basin. Alluvial deposits dominate in the irrigated lands and plain range lands, but on the non-irrigated plains out-washed gravely Arenosols are the dominating soils, whereas outside the flood plains (drier areas) the soils are dominated by Leptosols and Regosols (Yirgalem, 2001). The main soil type of the experimental site was calcareous Fluvisol (FAO/UNESCO, 1994).

\section{Experimental design and treatments}

The experiments were laid out in randomized complete block designs with three replications. In the 2009 crop season, the effect of five $\mathrm{N}$ rates $(\mathrm{N} 0=0, \mathrm{~N} 1=36, \mathrm{~N} 2=59, \mathrm{~N} 3=82$ and $\mathrm{N} 4=105 \mathrm{~kg}$ $\mathrm{N}$ ha ${ }^{-1}$ ) without $\mathrm{S}$ and in 2010 crop season, a factorial combination of the same five $\mathrm{N}$ rates with three rates of $\mathrm{S}(\mathrm{S} 0=0, \mathrm{~S} 1=20$ and $\mathrm{S} 2=40 \mathrm{~kg} \mathrm{~S} \mathrm{ha}^{-1}$ ) were used in $2.1 \times 3 \mathrm{~m}^{2}$ plots to determine the response of the NERICA-4 rice variety to $\mathrm{N}$ and $\mathrm{S}$. Urea, ammonium sulphate, were used as $\mathrm{N}$ and $\mathrm{S}$ sources. Potassium sulphate was also used as source of $S$ to plots with the treatment 
combinations with $\mathrm{S}$ but not $\mathrm{N}$. Urea and ammonium sulphate fertilizers were applied in three split applications (the first $1 / 3$ at sowing, the second $1 / 3$ at tillering, and the remaining $1 / 3$ during panicle initiation) as mentioned in Beyene and Aberra (1998). As basal treatments, $20 \mathrm{~kg} \mathrm{P} \mathrm{ha}^{-1}$ and $50 \mathrm{~kg} \mathrm{~K} \mathrm{ha}^{-1}$ in the form of triple super phosphate and chloride of potash were applied to all plots during sowing.

The dry rice seeds were sown by hand at row spacing of $30 \mathrm{~cm}$ and seed rate of $60 \mathrm{~kg} \mathrm{ha}^{-1}$. Thinning of the seedlings was carried out one week after emergence of the rice seedlings to maintain their spacing at $15 \mathrm{~cm}$ within the row. Weeding of the rice plots was conducted manually by hand three times, at 20, 40 and 60 days after sowing. The irrigation water required to raise the crop was pumped from the middle Awash River. Irrigation water schedule was set initially at 4-day intervals and depth of $26 \mathrm{~mm}$ until tillering, and as 6-day and depth of $52 \mathrm{~mm}$ till 15 days before harvest using the CROPWAT- 8 software (FAO, 2001).

\section{Calculation of nitrogen use efficiency components}

Nitrogen use efficiency generally accounts for the quantity of $\mathrm{N}$ accumulated in the plant, showing the $\mathrm{N}$ uptake efficiency and the quantity of $\mathrm{N}$ utilized in grain production or the $\mathrm{N}$ utilization efficiency of the plant to applied N. The NUE components: Apparent $\mathrm{N}$ recovery efficiency (ANRE), physiological $\mathrm{N}$ use efficiency (PNUE), and agronomic $\mathrm{N}$ use efficiency (ANUE) were calculated as given in Craswell and Godwin (1984), using the expressions:

$$
\begin{aligned}
& \text { Apparent recovery efficiency }(\%)=\frac{\mathrm{N}_{\mathrm{f}}-\mathrm{N}_{\mathrm{c}}}{\mathrm{NA}} \times 100 \\
& \text { Physiological efficiency }\left(\mathrm{kg} \mathrm{kg}^{-1}\right)=\frac{\mathrm{G}_{\mathrm{f}}-\mathrm{G}_{\mathrm{c}}}{\mathrm{N}_{\mathrm{f}}-\mathrm{N}_{\mathrm{c}}} \\
& \text { Agronomic efficiency }\left(\mathrm{kg} \mathrm{kg}^{-1}\right)=\frac{\mathrm{G}_{\mathrm{f}}-\mathrm{G}_{\mathrm{c}}}{\mathrm{NA}}
\end{aligned}
$$

where, $N_{f}$ and $N_{c}$ refer to the total above ground plant dry matter- $N$ content $\left(\mathrm{kg} \mathrm{ha}^{-1}\right)$ in the fertilized and control (unfertilized) plots, $\mathrm{G}_{\mathrm{f}}$ and $\mathrm{G}_{\mathrm{c}}$ refer to grain yield $\left(\mathrm{kg} \mathrm{ha}^{-1}\right)$ in the fertilized and control plots, and NA is the amount of fertilizer- $\mathrm{N}$ in $\mathrm{kg} \mathrm{ha}^{-1}$ applied. Apparent recovery efficiency is based on the measurement of nitrogen uptake by the above-ground plant part and reflects the efficiency of the crop in obtaining $\mathrm{N}$ from fertilizer with the assumption that fertilized and control crops absorb the same amount of soil $\mathrm{N}$, while the physiological efficiency measures the efficiency with which the crop utilizes $\mathrm{N}$ in the plant for the synthesis of grain. The agronomic efficiency, which is the product of apparent recovery and physiological efficiency, reflects the overall efficiency with which applied $\mathrm{N}$ is used.

\section{Yield and yield components}

The grain, straw and total dry matter yields were measured at maturity by harvesting the three central rows of $2.7 \mathrm{~m}^{2}$ area of each plot and adjusting the grain moisture content to $12 \%$. Number of panicle per plant, number of grain per panicle, panicle length, stem length, leaf area and number of tiller per plant were measured before physiological maturity from 10 plants randomly selected from each plot. Leaf area index ( $\mathrm{LAl}$ ) was recorded by the length-width method (Reddy, 2006) during panicle initiation using 0.725 adjustment factor (Tsunoda, 1964).

\section{Soil, plant and water analysis}

Composite soil samples from the 0 to $20 \mathrm{~cm}$ depths were collected one month before sowing. Soil samples after drying and sieving were analyzed for $\mathrm{pH}$ (1:2.5 soil: water ratio), and $\mathrm{EC}_{e}$ of the saturated paste extract. Soil bulk density (BD) was measured by the core method (Blake and Hartage, 1986) and soil organic carbon (SOC) was analyzed by Walkley and Black method (Nelson and Sommers, 1982). Total soil N (TN) was determined as total kjeldahal $\mathrm{N}$ (Bremer and Mulvaney, 1982), available-P was extracted using $0.5 \mathrm{M} \mathrm{NaHCO}_{3}$ at $\mathrm{pH} 8.5$ and determined as mentioned in Olsen and Sommers (1982), and extractable K was analyzed as given in Knudsen et al. (1982). The $\mathrm{KH}_{2} \mathrm{PO}_{4}$ soluble soil-S was determined by the turbidmetric method (Woomer et al., 2001).

To assess the effect of $\mathrm{N}$ and $\mathrm{S}$ fertilization on the $\mathrm{N}$ content of the rice crop, leaf, straw and grain samples were analyzed for total $\mathrm{N}$. Three top leaves per plant were sampled from ten randomly picked plants for each plot at panicle initiation. Grain and straw were sampled from the harvested rice of each plot after separating the dry matter to grain and straw. The plant leaves, straw and grain samples were oven dried at $70^{\circ} \mathrm{C}$ for $48 \mathrm{~h}$, and the dried material was ground to pass through $1-\mathrm{mm}$ sieve. Total plant $\mathrm{N}$ was analyzed using the kjeldahal method as given in Bremer and Mulvaney (1982). The grain crude protein content was calculated by multiplying the percent grain $\mathrm{N}$ by the constant factor of 6.25 (AOAC, 1994).

The $\mathrm{pH}$ and $\mathrm{EC}_{\mathrm{w}}$ of the irrigation water was measured using $\mathrm{pH}$ and $\mathrm{EC}$ meters. The $\mathrm{HCO}_{3}{ }^{-}$concentration was determined by acidimetric titration. The nitrate $\left(\mathrm{NO}_{3}^{-}\right)$and ammonium $\left(\mathrm{NH}_{4}^{+}\right)$ion concentration in the water was determined as given in Jackson (2003). The $\mathrm{SO}_{4}{ }^{-2}$ ion concentration was determined by the turbidmetric method and the $\mathrm{Cl}^{-}$ion water content was determined by the method described in Rhoades (1982). The $\mathrm{Na}^{+}$and $\mathrm{K}^{+}$ion concentration were determined from their ammonium acetate extract, using flame photometer. The $\mathrm{Ca}^{+2}$ and $\mathrm{Mg}^{+2}$ ion water concentration were analyzed by the EDTA titration method follwing their ammonium acetate extract (Suarez, 2001).

\section{Statistical analysis}

Field data was statistically analyzed using the SAS 9.1 statistical procedure (2003). Analysis of variance (ANOVA) was performed to evaluate the effect of the main factors $N$ and $S$ fertilizer treatments and their interaction on yield, yield components, nitrogen use efficiencies, and $\mathrm{N}$ uptake and protein content of the rice plant. Comparisons among the treatment means were made using Fisher's LSD test. Yield differences across years were compared using the match paired $t$-test. Correlation analysis between yield and yield components were conducted and the components that determine most of the grain yield variations were separated using the stepwise regression analysis. $\mathrm{F}$ and $t$ significance level tests were made at $P<0.05$, until and unless stated otherwise.

\section{RESULTS AND DISCUSSION}

\section{Properties of the soil and irrigation water}

Some of the selected physical and chemical properties of the surface soil $(0$ to $20 \mathrm{~cm}$ ) and the water used for irrigation are presented in Table 1. The soil was alkaline in $\mathrm{pH}$, low in SOM content and water-holding capacity (Table 1). The total $\mathrm{N}$ content of the soil was in the low sufficiency range $(<0.1 \%)$ (Tekalign et al., 1991) and the 
Table 1. Some selected physical and chemical properties of the surface soil $(0-0.2 \mathrm{~m})$ of the experimental site and irrigation water.

\begin{tabular}{lclc}
\hline Soil properties & Measured value & Water properties & Measured value \\
\hline $\mathrm{pH}(1: 2.5$ soil water suspension) & 8.34 & $\mathrm{pH}$ & 8.35 \\
Electrical conductivity of soil extract $\left(\mathrm{dSm}^{-1}\right)$ & 1.17 & Electrical conductivity $\left(\mathrm{dSm}^{-1}\right)$ & 0.13 \\
Bulk density $\left(\mathrm{g} \mathrm{cm}^{-3}\right)$ & 1.14 & Dissolved ions $(\mathrm{mEq} \mathrm{I})^{-1}$ & \\
Organic carbon $(\%)$ & 1.3 & $\mathrm{Ca}^{+2}$ & 044 \\
Available- $\mathrm{P}\left(\mathrm{mg} \mathrm{kg}^{-1}\right)$ & 5.4 & $\mathrm{Mg}^{+2}$ & 0.63 \\
Available-K $\left(\mathrm{mg} \mathrm{kg}^{-1}\right)$ & 194 & $\mathrm{Na}^{+}$ & 1.84 \\
Available-S $\left(\mathrm{mg} \mathrm{kg}^{-1}\right)$ & 5.7 & $\mathrm{~K}^{+}$ & 0.51 \\
Total-N $(\%)$ & 0.09 & $\mathrm{NH}_{4}^{+}$ & 0.02 \\
Particle size analysis & & $\mathrm{NO}_{3}{ }^{-}$ & 0.02 \\
Clay (\%) & 15 & $\mathrm{HCO}_{3}^{-}$ & 10.7 \\
Silt $(\%)$ & 18 & $\mathrm{Cl}^{-}$ & 2.57 \\
Sand $(\%)$ & 67 & $\mathrm{SO}_{4}^{-2}$ & 0.01 \\
Volumetric water content $\left(\mathrm{m}^{3} \mathrm{~m}^{-3}\right)$ & & & \\
Field capacity & 0.40 & & \\
Permanent wilting point & 0.18 & & \\
\hline
\end{tabular}

Table 2. Effect of $\mathrm{N}$ rates on yield and yield components of upland rice for the 2009 season.

\begin{tabular}{|c|c|c|c|c|c|c|c|}
\hline \multirow{2}{*}{$\mathrm{N}$ rates } & \multicolumn{3}{|c|}{ Yield $\left(\mathrm{Mg} \mathrm{ha}^{-1}\right)$} & \multirow{2}{*}{$\% \mathrm{HI}$} & No. panicles & No. tillers & \multirow{2}{*}{ Stem length $(\mathrm{cm})$} \\
\hline & Grain & Straw & Tot. DM & & \multicolumn{2}{|c|}{ Plant $^{-1}$} & \\
\hline No & 1.72 & 5.02 & 6.74 & 25.5 & 6.7 & 4.3 & 60.2 \\
\hline N1 & 2.04 & 5.98 & 8.02 & 25.5 & 8.1 & 5.0 & 63.4 \\
\hline $\mathrm{N} 2$ & 2.34 & 6.29 & 8.63 & 27.2 & 9.0 & 5.5 & 66.1 \\
\hline N3 & 2.51 & 7.07 & 9.58 & 26.2 & 8.9 & 5.7 & 70.8 \\
\hline N4 & 2.79 & 7.80 & 10.59 & 26.3 & 9.3 & 6.0 & 72.5 \\
\hline LSD & 0.12 & 0.39 & 0.38 & $\mathrm{~ns}$ & 0.34 & 0.26 & 0.80 \\
\hline $\mathrm{R}^{2}$ & 0.98 & 0.97 & 0.98 & 0.41 & 0.98 & 0.96 & 0.99 \\
\hline
\end{tabular}

F test significance level $(P<0.05)$; $\mathrm{HI}=$ harvest index; ns=non significant; $\mathrm{N0}=0, \mathrm{~N} 1=36, \mathrm{~N} 2=59, \mathrm{~N} 3=82, \mathrm{~N} 4=105 \mathrm{~kg} \mathrm{~N}^{-1}$.

available-P was also in the low category (4 to $7 \mathrm{mg} \mathrm{kg}^{-1}$ ) (Olsen et al., 1954). It was also deficient in extractable-S $\left(0\right.$ to $\left.7 \mathrm{mg} \mathrm{kg}^{-1}\right)$ but high $\left(>160 \mathrm{mg} \mathrm{kg}^{-1}\right)$ in exchangeable$\mathrm{K}$ (Tisdale et al., 2005).

Irrigation water with a $\mathrm{pH}$ value in the range of 6.5 to 8.4, SAR less than 3 , and ${E C_{w}}_{w}$ less than 0.7 is considered suitable for irrigation (Ayers and Westcot, 1985). The irrigation water analysis results for the same parameters mentioned previously indicate that the quality of the water used was suitable for irrigation (Table 1) The irrigation water contained low dissolved inorganic- $\mathrm{N}$ ions $\left(\mathrm{NO}_{3}^{-}\right.$and $\left.\mathrm{NH}_{4}^{+}\right)$and $\mathrm{S}$ ions $\left(\mathrm{SO}_{4}{ }^{-2}\right)$ (Pasricha and Fox, 1993; Beyene and Aberra, 1998). In the present work the upland rice variety responded well to $\mathrm{N}$ and $\mathrm{S}$ fertilization, as the availability of these nutrients in the soil and water is very low

\section{Yield and yield components}

The response of grain, straw, and total above-ground dry matter yield (DM), and the yield attributes such as number of panicles and tillers, and stem length of the upland rice plant to $\mathrm{N}$ fertilization for the 2009 crop season are shown in Table 2. Similarly, the response of grain, straw and total dry matter yield, and yield attributes like numbers of grain, panicle and tillers; lengths of panicle and stem, and leaf area of the same crop to combined $\mathrm{N}$ and $\mathrm{S}$ fertilization for the 2010 crop season are given in Table 3 .

All the $N$ rates applied in 2009 crop season, significantly $(P=0.05)$ increased the yield and yield attributes of rice, but the \%HI was non-significant to $\mathrm{N}$ fertilization. Similar significant responses to yield and yield components were also observed at all $\mathrm{N}$ and $\mathrm{S}$ application rates and their interactions during the 2010 crop season. The \%HI was nonsignificant to $\mathrm{N}$ when the $\mathrm{N}$ was added without $\mathrm{S}$, but responded significantly to $\mathrm{N}$ when fertilized with S (Table 3). The result in Table 2 and 3 shows an increase in straw yield when $\mathrm{N}$ was applied but the relative increase in the grain yield by $\mathrm{N}$ application was low. This either reduced or made little 
Table 3. Response of yield and yield components of rice to $\mathrm{N}$ and $\mathrm{S}$ for the 2010 crop season.

\begin{tabular}{|c|c|c|c|c|c|c|c|c|c|c|c|}
\hline \multirow{2}{*}{$\begin{array}{l}\mathrm{N} \text { and S rates } \\
\left(\mathrm{kg} \mathrm{ha}^{-1}\right)\end{array}$} & \multicolumn{3}{|c|}{ Yield $\left(\mathrm{Mg} \mathrm{ha}^{-1}\right)$} & \multirow{2}{*}{$\% \mathrm{HI}$} & \multirow{2}{*}{$\begin{array}{l}\text { Grain } \\
\text { wt. (g) }^{-1} \\
\text { plant }^{-1}\end{array}$} & \multirow{2}{*}{$\begin{array}{c}\text { No. } \\
\text { grain } \\
\text { panicle }^{-1}\end{array}$} & \multirow{2}{*}{$\begin{array}{l}\text { Leaf } \\
\text { area } \\
\left(\mathrm{cm}^{2}\right)\end{array}$} & $\begin{array}{c}\text { No. } \\
\text { panicle }\end{array}$ & \multirow{2}{*}{$\begin{array}{c}\begin{array}{c}\text { No. } \\
\text { tiller }\end{array} \\
-1\end{array}$} & \multirow{2}{*}{\multicolumn{2}{|c|}{$\frac{\text { Panicle Stem }}{\text { Length }(\mathrm{cm})}$}} \\
\hline & Grain & Straw & Tot. DM & & & & & plant $^{-1}$ & & & \\
\hline NOSO & 1.81 & 5.30 & 7.11 & 25.5 & 7.9 & 68.5 & 7.2 & 6.9 & 4.5 & 17.3 & 50.7 \\
\hline NoS1 & 1.87 & 6.19 & 8.06 & 23.2 & 8.4 & 69.3 & 7.3 & 7.9 & 4.8 & 17.8 & 51.6 \\
\hline NoS2 & 1.96 & 6.33 & 8.29 & 23.6 & 8.8 & 73.2 & 8.2 & 7.9 & 5.0 & 17.7 & 52.0 \\
\hline N1SO & 2.02 & 6.29 & 8.31 & 24.3 & 9.1 & 72.1 & 7.5 & 8.1 & 5.0 & 18.1 & 53.3 \\
\hline N1S1 & 2.19 & 6.45 & 8.64 & 25.3 & 9.9 & 77.9 & 8.1 & 8.4 & 5.9 & 19.0 & 55.1 \\
\hline N1S2 & 2.33 & 6.77 & 9.10 & 25.6 & 10.5 & 79.8 & 9.6 & 8.7 & 6.1 & 20.1 & 60.1 \\
\hline N2SO & 2.32 & 6.60 & 8.92 & 26.0 & 10.4 & 79.7 & 8.6 & 8.9 & 5.5 & 18.7 & 55.7 \\
\hline N2S1 & 2.49 & 7.76 & 10.25 & 24.3 & 11.2 & 81.0 & 9.1 & 9.3 & 6.1 & 20.4 & 56.9 \\
\hline N2S2 & 2.65 & 8.02 & 10.67 & 24.8 & 11.9 & 83.3 & 13.2 & 10.2 & 6.8 & 21.6 & 65.0 \\
\hline N3SO & 2.51 & 7.60 & 10.11 & 24.8 & 11.3 & 83.6 & 9.5 & 8.9 & 5.8 & 19.4 & 60.9 \\
\hline N3S1 & 2.95 & 8.63 & 11.58 & 25.5 & 13.3 & 86.8 & 11.0 & 9.5 & 6.5 & 21.5 & 60.8 \\
\hline N3S2 & 3.30 & 8.74 & 12.04 & 27.4 & 14.9 & 90.6 & 14.9 & 10.9 & 7.3 & 22.3 & 69.9 \\
\hline N4SO & 2.84 & 8.44 & 11.28 & 25.2 & 12.8 & 91.7 & 11.9 & 9.7 & 6.2 & 20.2 & 62.2 \\
\hline N4S1 & 3.33 & 9.24 & 12.57 & 26.5 & 15.0 & 94.7 & 13.7 & 10.5 & 7.0 & 22.3 & 65.2 \\
\hline N4S2 & 4.00 & 8.86 & 12.86 & 31.1 & 18.0 & 99.3 & 17.6 & 11.3 & 7.9 & 23.0 & 72.8 \\
\hline $\mathrm{LSD}_{\mathrm{N}}$ & 0.07 & 0.06 & 0.09 & 0.42 & 0.29 & 0.03 & 0.05 & 0.03 & 0.04 & 0.06 & 0.07 \\
\hline $\mathrm{LSD}_{\mathrm{S}}$ & 0.05 & 0.05 & 0.07 & 0.35 & 0.23 & 0.02 & 0.037 & 0.22 & 0.029 & 0.047 & 0.054 \\
\hline$L_{S D} D_{N^{*} S}$ & 0.11 & 0.11 & 0.16 & 0.79 & 0.51 & 0.05 & 0.08 & 0.10 & 0.10 & 0.10 & 0.12 \\
\hline $\mathrm{R}^{2}$ & 0.99 & 0.99 & 0.99 & 0.96 & 0.99 & 0.99 & 0.99 & 0.99 & 0.99 & 0.99 & 0.99 \\
\hline
\end{tabular}

$\mathrm{HI}=$ harvest index; $\mathrm{F}$ test significance level $(\mathrm{P}<0.05)$; No $=0, \mathrm{~N} 1=36, \mathrm{~N} 2=59, \mathrm{~N} 3=82, \mathrm{~N} 4=105 \mathrm{~kg} \mathrm{~N} \mathrm{ha}^{-1}, \mathrm{~S} 0=0, \mathrm{~S} 1=20, \mathrm{~S} 2=40 \mathrm{~kg} \mathrm{~S}^{-1}$.

difference to the value of the \%HI, which is commonly observed with $\mathrm{N}$ fertilization (Aamer et al., 2000; Habtegebrial and Singh, 2006). However, when $\mathrm{N}$ was applied with $\mathrm{S}$, the grain $\mathrm{N}$ utilization efficiency seems to increase (Table 4), which may have increased the grain yield relative to the straw yield.

Nitrogen application alone increased the grain and DM yield of upland rice, average for both crop seasons by 0.70 and $2.5 \mathrm{Mg} \mathrm{ha}^{-1}$, compared to the controls (N0). The application of the same $\mathrm{N}$ rates with $\mathrm{S}$ further improved the grain and DM yield on average by 0.5 and $1.3 \mathrm{Mg}$ ha ${ }^{1}$, compared to similar $\mathrm{N}$ rates without $\mathrm{S}\left(\mathrm{N}_{\mathrm{x}} \mathrm{S}_{0} \mathrm{X}=1,2,3\right.$, and 4). The combined application of $\mathrm{N}$ with $\mathrm{S}$ increased on average the grain and straw yield by 0.82 and $2.27 \mathrm{Mg}$ $\mathrm{ha}^{-1}$, respectively, compared to the control (NOSO). The highest grain yield was obtained when N4 (105 kg ha-1) was combined with S2 $\left(40 \mathrm{~kg} \mathrm{ha}^{-1}\right)$. The above findings on the effect of $\mathrm{N}$ fertilization on yield and yield components of upland rice variety are similar with the findings reported on the same crop by Walker et al. (2008) and Shiferaw et al. (2012). No grain yield differences across years $(t>0.453)$ to $\mathrm{N}$ fertilization was observed; however, the rice crop responded lineally to $\mathrm{N}$ applications in both years, indicating the possibility of further yield improvement at higher $\mathrm{N}$ rates $(\mathrm{N}>105 \mathrm{~kg}$ $\mathrm{ha}^{-1}$ ).

Response of crop growth and yield to the application of $S$ has been reported for many crops (Stabursvik and
Heide, 1974; Zhao et al., 1999; Habtegebrial and Singh, 2006), where, an insufficient $S$ supply can affect yield and quality of crops, caused by the $S$ requirement for protein and enzyme synthesis (Zhao et al., 1999). Ample N supply enhances the assimilation of ammonia, increasing both the protein content and leaf growth of crop plants, resulting with an increase in net photosynthesis (Marschner, 1997). Sulphur is also reported to enhance the photosynthetic assimilation of $\mathrm{N}$ in crop plants (Anderson, 1990; Ahmad and Abdin, 2000). Hence, the application of $\mathrm{N}$ and $\mathrm{S}$ fertilizers increases the net photosynthetic rate in crop plants, which in turn increases their dry matter and grain yield, as $90 \%$ of the plant's dry weight is considered to be derived from products formed during photosynthesis (Peoples et al., 1980).

Supply of $\mathrm{N}$ to grain crops is known to favor tillering (Evans et al., 1975), where, the number of ears per ha mainly depends on seed density and tillering capacity (Mengel and Kirkby, 2001). Nitrogen and S supply can also beneficially influence the initiation of spikelet/ or floret, which determines the number of grain per spike and the yield per head during ear development (Ewert and Honermeier, 1999; Zhao et al., 1999).

Grain weight plant $^{-1}$ was strongly correlated with number of grains panicle $e^{-1}(r=0.96)$, leaf area $(r=0.95)$, number of panicles plant ${ }^{-1}(r=0.95)$, number of tillers plant $^{-1}(r=0.95)$, panicle length $(r=0.94)$, and stem length $(r=0.94)$. Stepwise regression analysis showed 
Table 4. Effect of $\mathrm{N}$ and $\mathrm{S}$ applications on leaf and grain $\mathrm{N}$ concentration, $\mathrm{N}$-yield and \% protein.

\begin{tabular}{|c|c|c|c|c|c|}
\hline \multirow{2}{*}{$\mathrm{N}$ and $\mathrm{S}$ rates } & \multirow{2}{*}{$\begin{array}{c}\text { Leaf } \\
\mathrm{N}(\%) \\
\end{array}$} & \multirow{2}{*}{$\begin{array}{l}\text { Grain } \\
\mathrm{N}(\%) \\
\end{array}$} & \multicolumn{2}{|c|}{$N$ yield $\left(\mathrm{kg} \mathrm{ha}^{-1}\right)$} & \multirow{2}{*}{$\begin{array}{c}\text { Grain protein } \\
(\%)\end{array}$} \\
\hline & & & Grain & Total DM & \\
\hline NOSO & 0.40 & 1.21 & 17.7 & 47.1 & 7.5 \\
\hline NoS1 & 1.04 & 1.21 & 22.6 & 53.6 & 7.6 \\
\hline NoS2 & 1.08 & 1.21 & 23.7 & 53.2 & 7.6 \\
\hline N1S0 & 1.43 & 1.22 & 24.7 & 61.8 & 7.6 \\
\hline N1S1 & 1.46 & 1.23 & 27.0 & 67.5 & 7.7 \\
\hline N1S2 & 1.52 & 1.29 & 30.2 & 74.3 & 8.1 \\
\hline N2SO & 1.27 & 1.29 & 29.8 & 72.4 & 8.0 \\
\hline N2S1 & 1.23 & 1.39 & 34.5 & 90.0 & 8.7 \\
\hline N2S2 & 1.59 & 1.42 & 37.5 & 97.9 & 8.9 \\
\hline N3SO & 1.27 & 1.54 & 38.7 & 78.9 & 9.6 \\
\hline N3S1 & 1.51 & 1.74 & 51.4 & 115.3 & 10.9 \\
\hline N3S2 & 1.70 & 1.77 & 58.5 & 128.6 & 11.1 \\
\hline N4SO & 1.07 & 1.66 & 47.2 & 89.1 & 10.4 \\
\hline N4S1 & 1.73 & 1.78 & 59.3 & 132.2 & 11.1 \\
\hline N4S2 & 1.86 & 1.80 & 72.1 & 151.0 & 11.3 \\
\hline $\mathrm{LSD}_{\mathrm{N}}$ & 0.076 & 0.014 & 1.300 & 1.520 & 0.089 \\
\hline $\mathrm{LSD}_{\mathrm{S}}$ & 0.06 & 0.01 & 1.09 & 1.18 & 0.07 \\
\hline $\operatorname{LSD}_{\mathrm{N}^{*} \mathrm{~S}}$ & 0.11 & 0.03 & 2.26 & 2.66 & 0.16 \\
\hline$R^{2}$ & 0.94 & 0.99 & 0.99 & 0.99 & 0.99 \\
\hline
\end{tabular}

F test significance level $(P<0.05)$; N0 $=0, N 1=36, \mathrm{~N} 2=59, \mathrm{~N} 3=82, \mathrm{~N} 4=105 \mathrm{~kg} \mathrm{~N} \mathrm{ha}^{-1}, \mathrm{~S} 0=0, \mathrm{~S} 1=$ $20, \mathrm{~S} 2=40 \mathrm{~kg} \mathrm{~S} \mathrm{ha}^{-1}$.

that from among the five yield components that directly influence the grain weight plant $^{-1}$, the number of grain panicle ${ }^{-1}$ and number of tillers plant ${ }^{-1}$ account most of the variability in grain weight plant ${ }^{-1}\left(R^{2}=0.95\right)$ with the regression model: Grain weight plant ${ }^{-1}=-10.3+0.18$ (No. grain panicle ${ }^{-1}$ ) +1.14 (No. tillers plant ${ }^{-1}$ ), which is consistent with the definition of yield components that mainly determine the grain yield of crops (Mengel and Kirkby, 2001).

\section{Nitrogen uptake and protein content}

The $\mathrm{N}$ concentration in the leaf and grain tissues of the plant, the grain protein content and the $\mathrm{N}$ yield of the rice crop are shown in Table 4. The $\mathrm{N}$ concentration in the leaf and grain of the rice crop increased significantly $(P=$ 0.05 ) with increasing $\mathrm{N}$ rates. The $\mathrm{N}$ concentration of the leaf and grain of the rice crop were also observed to increase significantly with $\mathrm{S}$ rates, when applied with $\mathrm{N}$, showing strong positive interactions $(P<0.001)$. The leaf and grain $\mathrm{N}$ concentration increased on average by 0.9 and $0.2 \%$, while the grain and total dry matter $\mathrm{N}$ uptake increased on average by 17.4 and $28.5 \mathrm{~kg} \mathrm{ha}^{-1}$ when $\mathrm{N}$ was fertilized alone. On the other hand, the leaf and grain $\mathrm{N}$ concentration further increased when $\mathrm{N}$ was fertilized with $S$ by 0.3 and $0.1 \%$, while the grain and total dry matter $\mathrm{N}$ uptake was increased on average by 11.2 and $31.5 \mathrm{~kg} \mathrm{ha}^{-1}$, compared to the application of $\mathrm{N}$ without $\mathrm{S}$.
Similarly, the grain protein content increased on average by $1.4 \%$ with $\mathrm{N}$ alone, but further increased by $0.8 \%$ when the $\mathrm{N}$ was fertilized with $\mathrm{S}$, compared to the controls. Significant increase in N uptake and protein content of the rice plant with increasing $N$ rates was similarly reported by Mandana et al. (2011) and Shiferaw et al. (2012). Furthermore, many authors reported that the application of combined $\mathrm{N}$ and $\mathrm{S}$ was found to increase substantially the shoot and grain $\mathrm{N}$ content of field crops (Schung et al., 1993; Ahmad and Abdin, 2000). The significant positive interaction between $\mathrm{N}$ and $S$ in this experiment could be due to the metabolic coupling between $\mathrm{N}$ and $\mathrm{S}$ assimilations in the synthesis of S-containing amino acids and proteins, in which the $\mathrm{N}$ assimilation is down-regulated if the assimilation of $S$ slows down (Anderson, 1990).

\section{Nitrogen use efficiency components}

The response of the NUE components to combined $\mathrm{N}$ and $S$ fertilizer treatments are shown in Figures 1 to 3 . The response of ANRE (Figure 3) was significant, while PNUE (Figure 2) and ANUE (Figure 1) remained nonsignificant, although ANUE showed an increasing trend with $\mathrm{N}$ rates when $\mathrm{N}$ was applied alone.

The ANRE increased at first, reaching the highest at $\mathrm{N} 2$, and then declined at higher $\mathrm{N}$ rates, indicating that lower and higher $\mathrm{N}$ application were not useful for the 


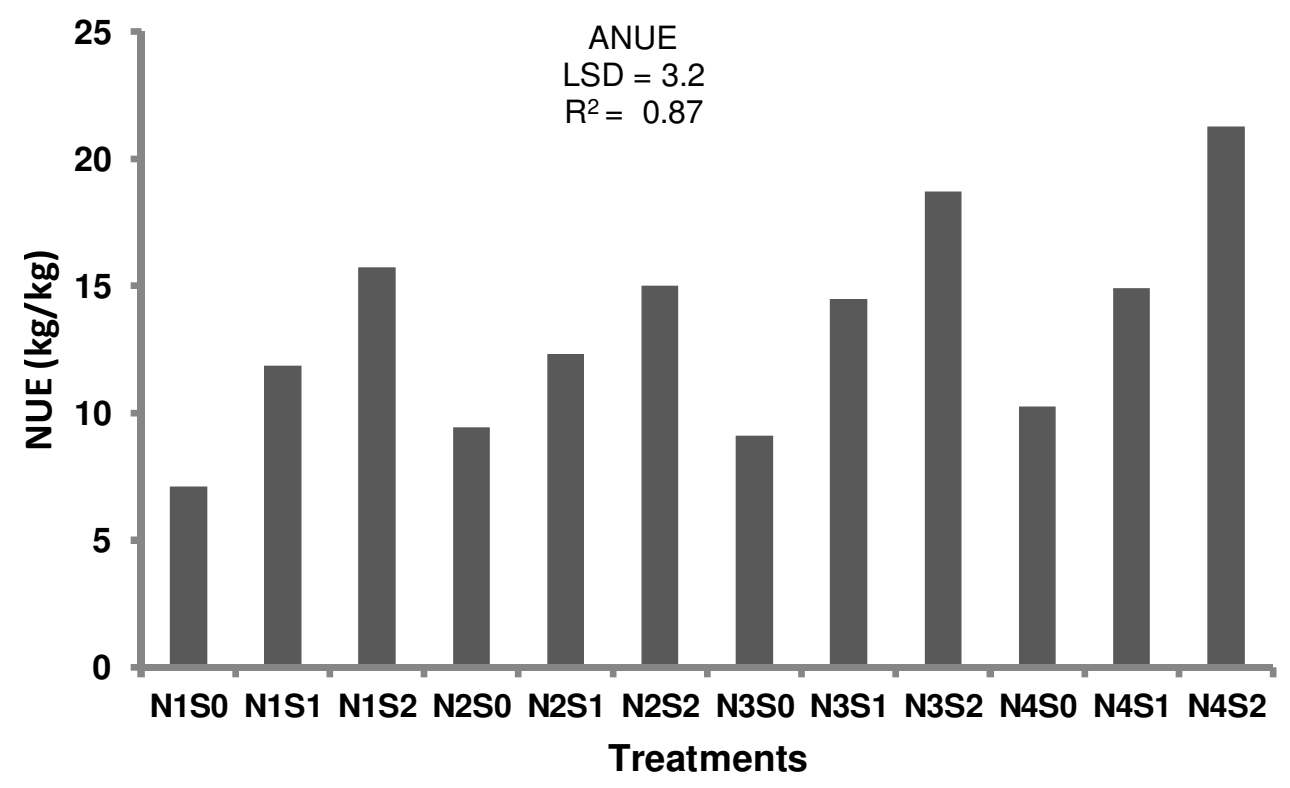

Figure 1. Effect of combined $\mathrm{N}$ and $\mathrm{S}$ fertilizer treatments on Agronomic NUE $(\mathrm{N} 0=0, \mathrm{~N} 1=36$, $\left.\mathrm{N} 2=59, \mathrm{~N} 3=82, \mathrm{~N} 4=105 \mathrm{~kg} \mathrm{~N} \mathrm{ha}^{-1}, \mathrm{~S} 0=0, \mathrm{~S} 1=20, \mathrm{~S} 2=40 \mathrm{~kg} \mathrm{~S} \mathrm{ha}^{-1}\right)$.

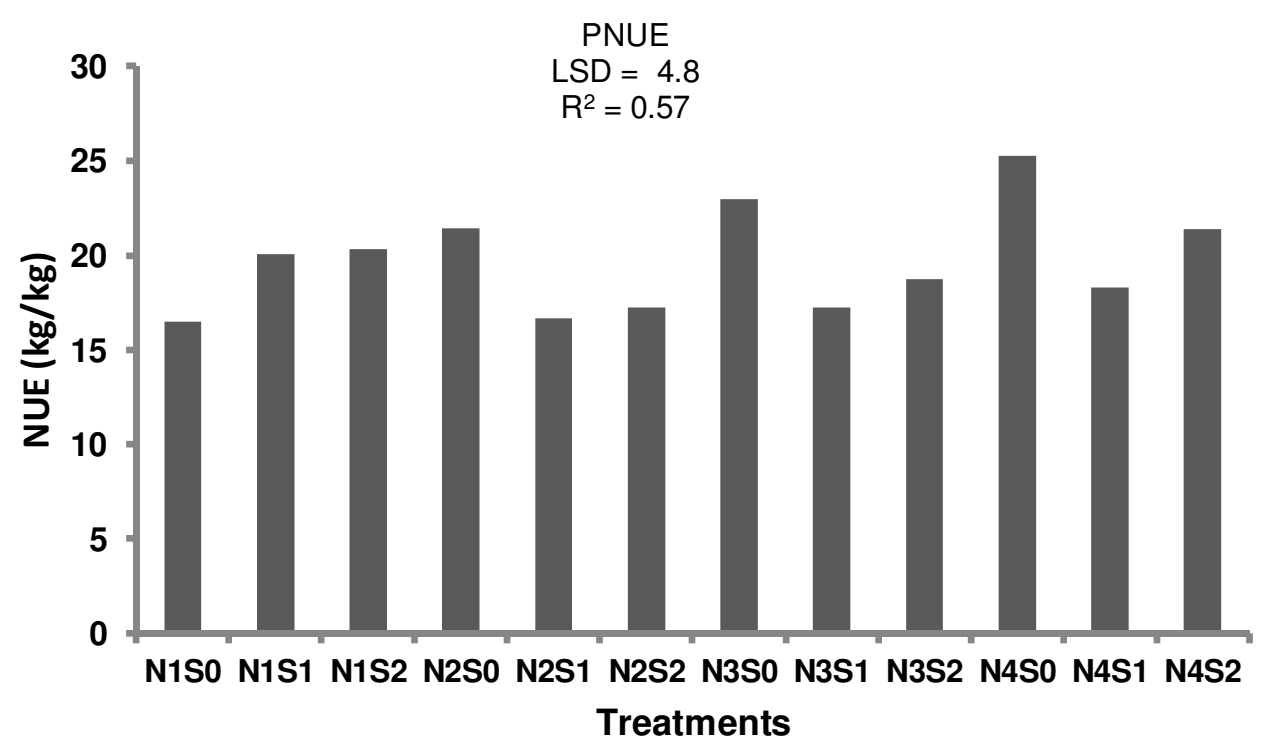

Figure 2. Effect of combined $\mathrm{N}$ and $\mathrm{S}$ fertilizer treatments on physiological $\mathrm{NUE}(\mathrm{N} 0=0, \mathrm{~N} 1=$ $\left.36, \mathrm{~N} 2=59, \mathrm{~N} 3=82, \mathrm{~N} 4=105 \mathrm{~kg} \mathrm{~N} \mathrm{ha}^{-1}, \mathrm{~S} 0=0, \mathrm{~S} 1=20, \mathrm{~S} 2=40 \mathrm{~kg} \mathrm{~S} \mathrm{ha}^{-1}\right)$.

$\mathrm{N}$ recovery. Similar observation was reported by Shiferaw et al. (2012) and Quanbao et al. (2007). In contrast, all the NUE components were significantly affected when $\mathrm{N}$ was applied with S. The ANRE and ANUE increased by $41 \%$ and $6.6 \mathrm{~kg} / \mathrm{kg}$, while the PNUE by $5.2 \mathrm{~kg} / \mathrm{kg}$. The substantial improvement on the NUE components of the rice crop when $\mathrm{N}$ is fertilized with $\mathrm{S}$ could be due the synergistic effect of $\mathrm{S}$ on $\mathrm{N}$ uptake and utilization that facilitates the biosynthesis of proteins, a vital process that determines yield. Therefore, using $\mathrm{N}$-fertilizers containing
$\mathrm{S}$, such as ammonium sulphate $\left[\left(\mathrm{NH}_{4}\right)_{2} \mathrm{SO}_{4}\right]$ or other multinutrient fertilizers with $\mathrm{N}$ and $\mathrm{S}$ blended in them may be advantageous to soils, deficient both in $\mathrm{N}$ and $\mathrm{S}$

\section{Conclusion}

In this experiment the upland rice variety performed better when $\mathrm{N}$ was fertilized with $\mathrm{S}$ than when $\mathrm{N}$ was applied alone; hence, the combined application of 


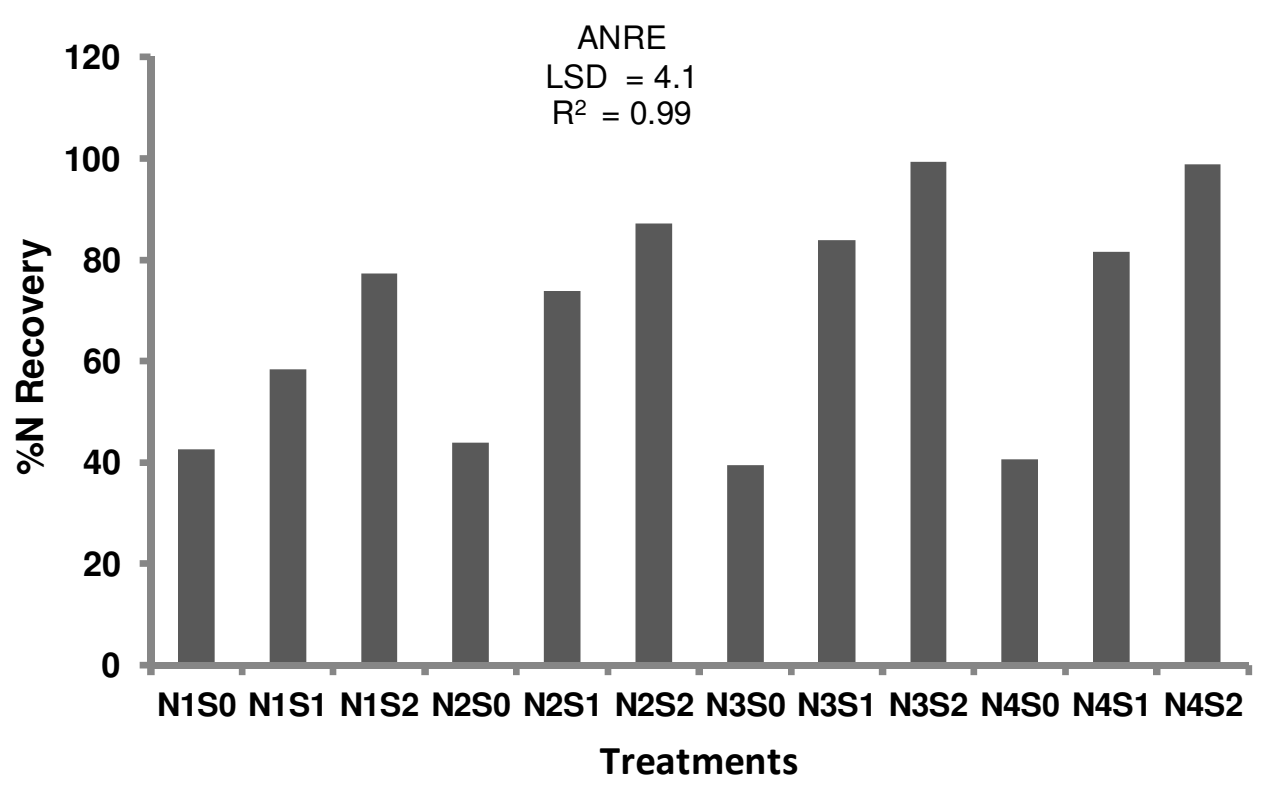

Figure 3. Effect of combined $\mathrm{N}$ and $\mathrm{S}$ fertilizer treatments on apparent $\mathrm{N}$ recovery efficiency $\left(\mathrm{N} 0=0, \mathrm{~N} 1=36, \mathrm{~N} 2=59, \mathrm{~N} 3=82, \mathrm{~N} 4=105 \mathrm{~kg} \mathrm{~N} \mathrm{ha}^{-1}, \mathrm{~S} 0=0, \mathrm{~S} 1=20, \mathrm{~S} 2=40 \mathrm{~kg} \mathrm{~S} \mathrm{ha}^{-1}\right)$.

$\mathrm{N}$ with $\mathrm{S}$ could be a feasible strategy to improve the yield and quality of upland rice, in soils containing suboptimal $\mathrm{S}$ and $\mathrm{N}$. The crop responded linearly to the application of $\mathrm{N}$ with the highest yield achieved at the highest $\mathrm{N}$ rate (N4), and was optimized further when N4 was added with S2, indicating that the yield of the crop can still be improved at further higher $\mathrm{N}$ rates, coupled with $\mathrm{S}$ fertilization. The ANRE and ANUE of rice were significantly maximized when $\mathrm{N}$ was fertilized with $\mathrm{S}$, which is an advantage to farmers, where the cost of fertilizers is expensive. Thus, applying $N$ with $S$ can substantially improve the yield, quality and NUE of upland rice, benefitting farmers, consumers, as well supporting the food self-sufficiency of the country.

\section{ACKNOWLEDGEMENT}

The authors duly acknowledge the Federal ATVET project and the Gewane College of Agriculture for their financial and technical support to conduct this study.

\section{REFERENCES}

Aamer I, Ghulam A, Abdul K (2000). Effect of different nitrogen application techniques on the yield and yield components of fine rice. Int. J. Agric. Biol. 2:3.

Ahmad A, Abdin MZ (2000). Photosynthesis and its physiological variables in the leaves of Brassica genotypes as influenced by $S$ fertilization. Physiol. Platarum. 110:144-149.

Anderson JW (1990). Sulphur metabolism on plants. In: Miflin, B.J., Lea, P.J (Eds). The biochemistry of plants vol. 16. Academic Press, New York. pp. 327-381.

AOAC (1994). Official Method of Analysis of the Association of Official Analytical Chemist, $12^{\text {th }}$ ed. Washington, DC.
Ayers D, Westcot F (1985). Water Resources: The Guidline for water quality interpretation of Irrigation water. Rome. Food and Agriculture Orgainzation of the United Nations.

Beyene S, Aberra A (1998). Agricultural research and technology transfer Attempts and achivements in Northern Ethiopia. Proceeding of the $4^{\text {th }}$ Technology Generation, Transfer and Gap Analysis Workshop. March 18-21, 1997. Bahir Dar, Ethiopia.

Blake GR, Hartage KH (1986). Bulk density. In: Klute, A (Ed.), Method of Soil Analysis, Part I. Physical and Mineralogical Methods, Agronomy Monograph No. $9,2^{\text {nd }}$ ed. SSSA, Madison, WI. pp. 363375.

Bremer JM, Mulvaney CA (1982). Total nitrogen. In: Page AL, Miller $\mathrm{RH}$, Keeny DR (Eds.). Methods of soil analysis part 2. Chemical and Microbiological Properties, Agronomy Monograph. $2^{\text {nd }}$ Ed. SSSA, Madison, WI. 9:595-622.

Ceccotti SP (1996). Plant nutrient sulphur-a review of nutrient balance, environmental impact and fertilizers. Feril. Res. 43:117-125.

Craswell ET, Godwin DC (1984). The efficiency of nitrogen fertilizers applied to cereals in different climates. In: Tinker B, Launch A. (Eds.), Advance in Plant Nutrition, vol.1 Preager, New York. pp. 1-55.

Evans LT, Wardlaw LF, Fischer RA (1975). Wheat. In: Crop Physiology. Cambridge University Press, edited by Evans LTP. pp. 101-149, Cambridge.

Ewert F, Honermeier B (1999). Spikelet initiation of winter triticale and winter wheat in response to nitrogen fertilization. Eur. J. Agron. 11:107-113.

FAO (2001). Irrigation guidelines on CD-ROM. Land and Water Digital Media Series Rome. P. 12.

FAO (2003). Sustainable rice production for food security. Proceedings of the 20th session of the International Rice Commission, July 23-24, 2002. Bangkok, Thailand.

FAO/UNESCO (1994). Soil map of the world, Africa, UNESCO, Paris. 14(6):299.

FARA (Forum for Agricultural Research in Africa) (2009). Patterns of change in rice production in Africa. Implications for rice policy development. Ministerial Policy Brief, Series P. 2, Accra, Ghana.

Gebrekidane H, Seyoum M (2006). Effects of mineral N and P fertilizers on yield and yield components of flooded lowland rice on vertisols of Foggera plain. Ethiopian J. Agric. Rural Dev. Trop. Subtrop. 107:161176.

Habtegebrial K, Singh BR (2006). Effects of timing of nitrogen and sulphur fertilizers on yield, nitrogen, and sulphur contents of Tef 
(Eragrostis tef (zucc.) Trotter). Nutr. Cycl. Agroecosyst. 75:213-222.

Inal A, Gunes A, Alpaaslan M, Adak MS, Taban S, Eraslan F (2003). Diagnosis of sulphur deficiency and effects of sulphur on yield and yield components of wheat grown in central Anatolia, Turkey. J. Plant Nutr. 26:1483-1498.

Itanna F (2005). Sulphur distribution in five Ethiopian Rift Valley soils under humid and semiarid climate. J. Arid Environ. 62:597-612.

Jackson M (2003). Soil Chemical Analysis. In Jasiwal P, Soil Plant and Water Analysis. Kalyani, New Delhi, India. pp. 106-120.

Knudsen D, Peterson GA, Pratt PE (1982). Lithium, sodium, and potassium. In: Page AL, Miller RH, Keeny DR. (Eds.). Methods of soil analysis part 2. Chemical and Microbiological Properties, Agronomy Monograph. $2^{\text {nd }}$ Ed. SSSA, Madison, WI. 9:225-246.

Mandana T, Gerayzade A, Ebrahim A, Azin NZ (2011). Effect of nitrogen fertilizer on nitrogen uptake, NUE of rice. Int. Conf. Biol. Environ. Chem. P. 24.

Marschner H (1997). Mineral Nutrition of Higher Plants. Academic Press, $5^{\text {th }}$ printing, Amsterdam, the Netherlands.

Mengel K, Kirkby EA (2001). Principles of Plant Nutrition. Kluwer Academic Publishers, $7^{\text {th }}$ edition, Dordrecht, The Netherlands. pp. 278-316.

Ministry of Agriculture and Rural Development (MoARD) (2010). Crop variety register. issue 13:30-35. Addis Ababa, Ethiopia.

Mulugeta S, Sentayehu A, Kassahun B (2011). Evaluation of upland NERICA Rice (Oryza sativa L.) genotypes for grain yield and yield components along an altitude gradient in Southwest Ethiopia. J. Agron. 10(4):105-111.

NAIA (2003). Rice varieties released. Crop Variety Regester. P. 6.

Nelson DW, Sommers LE (1982). Total carbon, organic carbon, and organic matter. In: Page AL, Miller RH, Keeny DR (Eds.). Methods of soil analysis part 2. Chemical and Microbiological Properties, Agronomy Monograph. $2^{\text {nd }}$ Ed. SSSA, Madison, WI. 9:539-579.

Oikeh SO, Nwilene F, Diatta S, Osiname S, Toure' O, Okeleye KA (2008). Responses of upland NERICA rice to nitrogen and phosphorous in forest agroecosystem. Agron. J. 100:735-741.

Olsen SR, Cole CV, Watanabe FS, Dean LA (1954). Estimation of available phosphorous in soils by extraction with sodium bicarbonate. US Dep. Agric. Circ. P. 939.

Olsen SR, Sommers LE (1982). Phosphorous. In: Page AL, Miller RH, Keeny DR (Eds.). Methods of soil analysis part 2. Chemical and Microbiological Properties, Agronomy Monograph. $2^{\text {nd }}$ Ed. SSSA, Madison, WI. 9:403-430.

Pasricha NS, Fox RL (1993). Plant nutrient sulphur in the tropics and subtropics. Adv. Agron. 50:209-269.

People MB, Beilharz VC, Waters SP, Simpson RJ, Dalling MJ (1980). Nitrogen redistribution during grain growth in wheat (Triticum aestivum L.). II. Chloroplast senescence and the degradation of ribulose 1,5-biphosphate carboxylase. Planta 149:241-251.

Quanbao Y, Hongcheng Z, Haiyan W, Ying Z, Benfo W, Ke X, Zhongyang H, Qigen D (2007). Effect of nitrogen fertilizers on nitrogen use efficiency and yield of rice under different soil conditions. Agric. China. 1(1):30-36.

Reddy SR (2006). Agronomy of field crops. Kalyoni Publishers, New Delhi, India. pp. 65-68.

Rhoades JD (1982). Soluble salts. In: Page AL, Miller RH, Keeny DR (Eds.). Methods of soil analysis part 2. Chemical and Microbiological Properties, Agronomy Monograph. $2^{\text {nd }}$ Ed. SSSA, Madison, WI. 9:575-601.
Samonte SOP, Wilson LT, Medley JC, Pinson SRM, McClung AM, Lales JS (2006). Nitrogen utilization efficiency; relationships with grain yield, grain protein, and yield-related traits of rice. Agron. J. 98:168-176.

SAS Institute (2003). SAS user's guide: Statistics Version 9.1; Statistical Analysis System Institute: Cary, NC.

Schung E, Hancklaus S, Murphy ND (1993). Impact of sulphur fertilization on fertilizer nitrogen efficiency. Sulphur Agric. 17;8-12.

Shiferaw N, Heluf G, Sharma JJ, Tareke B (2012). Effects of nitrogen sources and application on yield, yield attributes, and grain protein of rainfed NERICA-3 rice in Gambella, Ethiopia. Int. J. Agron. Agric. Res. 2(9):14-32.

Stabursvik A, Heide OM (1974). Protein content and amino acid spectrum of finger millet (Eleusine coracana (L.) Gaertn) as influenced by nitrogen and sulphur fertilizers. Plant Soil 41:549-571.

Suarez DL (2001). Beryllium, magnesium, calcium, strontium, and barium. In: Page AL (Ed.). Methods of soil analysis part 3. Chemical Methods, $3^{\text {rd }}$ printing. SSSA, Madison, WI. 5:167-179.

Tekalign T, Haque L, Aduayi EA (1991). Soil, plant, water, fertilizer, animal manure and compost analysis manual. Plant Science Division Working Document 13, ILCA, Addis Ababa, Ethiopia.

Tisdale SL, Havlin JL, Beaton JD, Nelson WL (2005). Soil Fertility and Fertilizers-An Introduction to Nutrient Management. $7^{\text {th }}$ edition, Prentice Hall, New Jersey.

Tsunoda S (1964). A development analysis of yield ability in varieties of field crops. Nihon Gakujitsu Shinkokai, Tokyo, Japan.

Walker TW, Bond TA, Ottis BV, Gerard PD, Harrel DL (2008). Hybrid rice response to nitrogen fertilization for mid southern United States rice production. Agron. J. 100:381-386.

WARDA (2001). NERICA rice for life Bouake 01, Cote d'Ivoire, pp. 8 http/www.warda.cgiar.org/publications/NERICA-8, pdf (accessed on Jan. 10, 2012).

Woomer PL, Okalebo JR, Gathua KW (2001). Laboratory methods of soil and plant analysis: a working manual $2^{\text {nd }}$ edition. Nairobi, Kenya. pp. 67-68.

Yasmin N, Blair G, Till R (2007). Effect of elemental sulphur, gypsum, and elemental sulphur coated fertilizers on the availability of sulphur to rice. J. Plant Nutr. 30:79-91.

Yirgalem A (2001). Challenges, opportunities and prospects of common property resource managment in the Afar pastoral area. FARM Africa, Addis Ababa, Ethiopia.

Zenna NS, Gebretsadic Z, Berhe T (2008). Moving up in Ethiopia Rice Today, $\quad \mathrm{http} / / \mathrm{irri}$.org/knowledge/publications/rice-today/featuresAfrica/moving-up-in-Ethiopia.

Zhao FJ, Hawkesford MJ, McGrath SP (1999). Sulphur assimilation and effects on yield and quality of wheat. J. Cereal Sci. 30:1-17. 